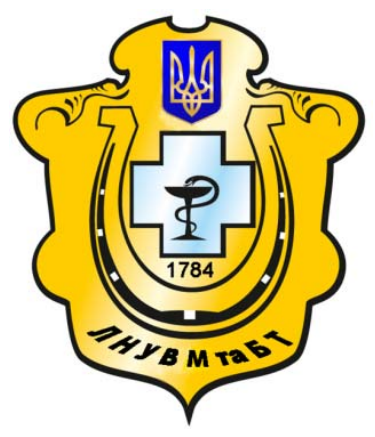

Науковий вісник Львівського національного університету ветеринарної медицини та біотехнологій імені С.3. Гжицького

Scientific Messenger of Lviv National University of Veterinary Medicine and Biotechnologies named after S.Z. Gzhytskyj

doi:10.15421/nvlvet7720

ISSN 2518-7554 print

ISSN 2518-1327 online

$\underline{\text { http://nvlvet.com.ua/ }}$

УДК 581. 19

\title{
Вміст біологічно активних речовин у різних видів роду Verbascum L.
}

\author{
М.Р. Грицина \\ hrytsynamr@gmail.com
}

\begin{abstract}
Львівський національний університет ветеринарної медицини та біотехнологій імені С.3. Гжицького, вул. Пекарська, 50, м. Львів, 79010, Украӥна
\end{abstract}

\begin{abstract}
B статті описані результати досліджень вмісту біологічно активних речовин в органах рослин видів роду Verbascum L. з родини Scrophulariaceae L.: V. thapsiforme Schrad., V. phlomoides L., V. lychnitis L, V. nigrum L., V. blattaria L., V. phoeniceum L. Дослідження вмісту біологічно активних речовин в органах різних видів рослин проводили за методикою Н.I. Гринкевич. Внаслідок проведених досліджень було встановлено, що всі види роду, нагромаджують у підземних $і$ надземних органах такі біологічно активні речовини: алкалоїди, кумарини, флавоноїди, сапоніни, дубильні речовини, водорозчинні полічукри та аскорбінову кислоту. Встановлена деяка прив'язаність вмісту БАР залежно від систематичного положення виду. Що стосується алкалоїдів, то в розеткових листках сильноопушених видів V. thapsiforme $i$ V. phlomoides з nidceкції Heterandra $i$ $V$. lychnitis з niдсекиї Isandra їх є значно більше, ніж в інших органах. У менш опушених, фіолетово забарвлених видів - V. nigrum, V. blattaria i V. phoепісеит виявлено їх сліди. У великій кількості сапоніни виявлено у всіх органах V. thapsiforme. Дещуо менший вміст ицих речовин є у близького виду V. phlomoides з підсекиї Heterandra. Інші види, які є неофіцинальними, також нагромаджують сапоніни. Так, V. lychnitis з підсекиіï Isandra у коренях і розеткових листках у великій кількості, дешь менше у стеблових листках і пелюстках, як $і$ V. nigrum - у всіх органах, в дуже великій кількості синтезують сапоніни. Великий вміст сапонінів виявлено у V. blattaria i V. phoепiceuт з іншої секиї̈ Singuliflora. У досліджуваних видів виявлені дубильні речовини, особливо в великій кількості у V. lychnitis V. nigrum i V. phlomoides. Флавоноїди нагромаджуються у всіх органах досліджених видів, а у V. nigrum, V. blattaria $i$ V. phoепісеит, щңо мають фіолетово забарвлені елементи квітки дуже великій кількості в пелюстках квіток. Кумарини в значно більшій кількості виявлені в розеткових листках пагонів першого року життя та коренях, ніж в стеблових листках та пелюстках квіток. Дещь менший їх вміст $є$ у надземній частині V. blattaria і пелюстках V. phoепiceuт з секиіï Singuliflora. У великій кількості синтезуються у всіх видів водорозчинні поліиукри, особливо багато їх є у коренях. В найбільшій кількості аскорбінова кислота міститься в пелюстках квіток $V$. lychnitis $i$ V. nigrum, тимчасом як в інших органах - іï є дуже мала кількість. $V$ V. blattaria, V. thapsiforme $i$ V. Phlomoides, навпаки, у розеткових листках вона є в дуже великій кількості, а в пелюстках - дуже мало.

Ключові слова: види роду Verbascum L., біологічно активні речовини, алкалоїди, кумарини, флавоноїди, сапоніни, дубильні речовини, водорозчинні поліщукри, аскорбінова кислота.
\end{abstract}

\section{Содержание биологически активных веществ в различных видов рода Verbascum $L$.}

\author{
М.Р. Грицина \\ hrytsynamr@gmail.com
}

Львовский национальный университет ветеринарной медицины и биотехнологий имени С.3. Гжицкого, ул. Пекарская, 50, г. Львов, 79010, Украина

В статье описаны результаты исследований содержания биологически активных веществ в органах растений видов рода Verbascum L. из семейства Scrophulariaceae L.: V. thapsiforme Schrad., V. phlomoides L., V. lychnitis, V. nigrum L., $V$. blattaria L., V. phoеniceum L. Исследование содержания биологически активных вещееств в органах различных видов рас-

\section{Citation:}

Hrytsyna, M.R. (2017). The content of biologically active substances in different kinds of species genus Verbascum L. Scientific Messenger LNUVMBT named after S.Z. Gzhytskyj, 19(77), 86-91. 
тений проводили по методике Н.И. Гринкевич. Вследствие проведенных исследований, было установлено, что все виды рода накапливают в подземных и надземных органах биологически активные вещества: алкалоиды, кумарины, флавоноиды, сапонины, дубильные вещества, водорастворимые полииукры и аскорбиновую кислоту. Установлена некоторая привязанность содержания БАВ от систематического положения вида. Что касается алкалоидов, то в розеточных листьях сильноопушених видов $V$. thapsiforme $u \mathrm{~V}$. phlomoides с подсекции Heterandra $u$ V. lychnitis c подсекции Isandra их содержание значительно больше, чем в других органах. B менее опушенных, фиолетово окрашенных видов - V. nigruт, V. blattaria $и$ V. phоепісеит обнаружено только следы этих веществ. В большом количестве сапонины обнаружены во всех органах $V$. thapsiforme. Несколько меньшее их содержание у близкого вида V. phlomoides с подсекции Неtеrandra. Другие виды, которье являются неофицинальными, также накапливают сапонины. Так, V. lychnitis из подсекиии Isапдra в корнях и розеточных листьях в большом количестве, несколько меньше в стеблевых листьях и лепестках, V. піgrит во всех органах, в очень больиом количестве. Большое содержание сапонинов обнаружено в V. blattaria u V. phoеniceum c дpyгой секции Singuliflora. У всех видов обнаружень дубильные вещества, особенно в большом количестве в V. lychnitis $V$. nigrum u $V$. phlomoides. Флавоноиды накапливаются во всех органах исследованных видов, а в V. nigrum, V. blattaria u V. phoепісеит, имеюших фиолетово окрашенные элементы цветка - в очень большом количестве в лепестках иветков. Кумарины в значительно большем количестве накапливаются в розеточных листьях побегов первого года жизни и корнях, чем в стеблевых листьях и лепестках иветов. Несколько меньше их содержание в надземной части V. blattaria и лепестках V. phоепісеит из секции Singuliflora. В большом количестве синтезируются у всех видов водорастворимье полииуглероды, особенно много их в корнях. В наибольшем количестве аскорбиновая кислота содержится в лепестках иветков V. lychnitis $u$ V. піgrит, тогда как в других органах - их очень малое количество. B V. blattaria, $V$. thapsiforme u V. Phlomoides, наоборот, в розеточньх листьях она содержится в очень большом количестве, а в лепестках - очень мало.

Ключевые слова: виды рода Verbascum L, биологически активные вещеества, алкалоиды, кумарины, флавоноиды, сапонины, дубильные вещества, водорастворимые полиуглероды, аскорбиновая кислота.

\title{
The content of biologically active substances in different kinds of species genus Verbascum L.
}

\author{
M.R. Hrytsyna \\ hrytsynamr@gmail.com \\ Lviv national university of veterinary medicine and biotechnologies named after S. Gzhytskyj, \\ Pekarska Str., 50, Lviv, 79010, Ukraine
}

In the article are described results of exploration 's biologically active substances in species of plant organs of genus Verbascum $L$, from the family of Scrophulariaceae L: V. thapsiforme Schrad., V. phlomoides L., V. lychnitis L, V. nigrum L., V. blattaria L., V. phoeniceum L. The exploration of biologically active substances in species of plant organs was conducted by N.I. Hrynkevych`s method. Including all explorations, was established that all species of sort accumulated at underground and above-ground organs biologically - active substances such as: alkaloids, coumarin, flavonoids, saponins, tannins, and carbohydrates, ascorbic acid. It was established that some attachment of BAR content depends on systematic position of the species. What concerns alkaloids 'rosette leaves of woolly species like V. thapsiforme and V. phlomoides from subsection Heterandra and V. lychnitis have another subsection Isandra have much more alkaloids than the other species. In less woolly, purple colored species - V. nigrum, V. blattaria and V. phoeniceum only found their traces. A large number of saponins are found in all organs of $V$. thapsiforme. Slightly lower content in these substances is in close species of $V$. phlomoides from the subsection Heterandra. Other species, which are not used in medicine, also accumulate saponins. Thus, V. lychnitis from subsection of Isandra in roots and rosette leaves in huge amount. Slightly low amount is in stem leaves and petals, alike all organs of $V$. nigrum and in large number. A large number of saponins is found in $V$. blattaria and $V$. phoeniceum from another section of Singuliflora. In explored species are found tannins, especially in great amount in V. lychnitis V. nigrum and V. phlomoides. Flavonoids accumulate in all organs of explored species, and in V. nigrum, V. blattaria, $V$. phoeniceum, which have purple colored flower elements - in huge amount in petals. Coumarins in huge variety accumulate in rosette shoot leaves and roots at first year of life than in a stem leaves and flower petals. Their content is less in the aerial part of $V$. blattaria, petals $V$. phoeniceum from Singuliflora section. Synthesized in large quantities in all carbohydrates, which is in great amount at its roots. The highest number of ascorbic acid contained in the petals of flowers $V$. lychnitis and $V$. nigrum, when in other organs they are in small number. On the contrary, in $V$. blattaria, $V$. thapsiforme and $V$. phlomoides rosette of leaves, carbohydrates is in a very large number, and petals in very little.

Key words: sort of Verbascum L., biologically active substances, alkaloids, coumarin, flavonoids, saponins, tannins, carbohydrates, ascorbic acid.

\section{Вступ}

Використання рослин для лікування різноманітних захворювань сягає сивої давнини. Це стосується рослин з роду дивина, перші згадки про які зустрічаються ще в давньогрецькій міфології, коли Одіссей використовував іiі для відвернення чарів чаклунки Цирцеї. В Свропі дивина культивуються ще $з$ середніх віків, іiі вирощували ченці як «чаклунське» зілля з лікувальною метою.
В наш час види роду дивина (Verbascum L.) є лікарськими і застосовуються як в народній, так і офіційній медицині багатьох країн світу. Пелюстки квіток $V$. thapsiforme, $V$. phlomoides, $V$. thapsus є офіцинальними в Бельгії, Угорщині, Данії, Франції, Польщі, Чехії. Вони входили до складу Державної фармакопеї CCCP 1-7 видання (Hrodzynskoho, 1991; Budancev, 1996). Проте через недостатню вивченість не ввійшли до нового видання. 
Вивчення біохімічного складу і лікувальних властивостей видів роду Дивина (Verbascum L.) проводилося, в основному, у зарубіжних країнах. 3 літератури відомо, що у великій кількості в цих рослинах синтезуються сапоніни. Так, гемолітичний індекс $V$. lychnitis становить 2000, V. blattaria - 2500, V. thapsus i V. nigrum - 4000 (Shreter et al., 1969; Budancev, 1996). Німецькі та в'єтнамські науковці виділили з надземних частин $V$. songaricum тритерпенові сапоніни (Songarosaponin A, B i C) (Seifert et al., 1991). Польські вчені виявили два тритерпенові сапоніни у суцвітті $V$. nigrum (Klimek et al., 1992). Їх структури були визначено за допомогою хімічних і спектральних мето-

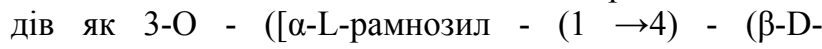
глікопіранозил - $(1 \rightarrow 3)]-\beta$-D глюкопіранозил] - $(1 \rightarrow$ $2)$ - $\beta$-фукопіранозіл) $-13 \beta, 28$ епоксилін -11-ен-3 $\beta$, 23 -діол та 3 -O - $([\alpha-\mathrm{L}-$ рамнозил - $(1 \rightarrow 4)$ - $(\beta-\mathrm{D}$ глюкопіранозил - $(1 \rightarrow 3)-\beta-\mathrm{D}$ - глюкопіранозил] - (1 $\rightarrow 2$ ) - $\beta$-фукопіранозіл) -11-метокси-олеан-12-ене- $3 \beta$, 23,28-тріол.

Іридоїдні глікозиди синтезуються також у всіх органах $V$. thapsiforme i $V$. phlomoides та листках $V$. blattaria. У $V$. lychnitis та $V$. thapsiforme ідентифіковано аукубін, ізокаталпол, каталпол, метилкаталпол, у V. Nigrum, окрім вищеперерахованих - аукубін та адонтозид, а у $V$. thapsus синтезується $1,7 \%$ аукубіну (Dohot et al., 1972; Karimova, 1974; Serdjuk et al., 1976; Swiatec et al., 1984; Budancev, 1996). Так, у V. thapsus було ідентифіковано п'ять нових іридоїдних глюкозидів, які об'єднано в дві групи. Перша - містить аюгол, друга - 6-O-( $\alpha$-L-рамнапіранозил)-каталпол (Warashina et al., 1991).

Новий ірідоідний глюкозид - вербаскоспінозид, було виділено з надземних частин $V$. spinosum. Його ідентифіковано як 6-О-[(2' '-О-транс-циннамоїл) - $\alpha$ L- рамнапіранозил]-каталпол. Окрім того, у цього виду було виявлено ірідоїди (аукубін, ізокаталпол, каталпол і аюгол) і три фенілпропаноідглікозиди (актеозид, ангорозид А і ангорозид С) (Kalpoutzakis et al., 1999). При фітохімічному дослідженні V. undulatum 3 його органів було виділено два нові ацильовані іридоїдні глікозиди (Magiatis et al., 2000). У надземній частині $V$. wiedemannianum флори Туреччини було виявлено п'ять ірідоідних глікозидів (аукубін, каталпол, аюгол, ангелозид, глютінозид), не-глікозидний іридоїд ремаглютин $\mathrm{D}$, два сапоніни, сітостерол-3-O- $\beta-\mathrm{D}$ глюкопіранозид і 5,7,3',4'-тетрагідрокси - флавоновий лютеолін (Gazar et al., 2003).

В різноманітних органах $V$. thapsus $i V$. lychnitis виявлено такі флавоноїди, як: кверцетин, кверцитрин, кверцимеритрин і рутин (Karimova, 1974; Nasyrov and Karimova, 1974; Serdjuk et al., 1976; Klimek and Krolikovska, 1984; Swiatec et al., 1984; Budancev, 1996; Danchul et al., 2007). Дубильні речовини містяться в невеликій кількості в листках всіх видів, лише $V$. thapsus нагромаджує до 6,5\% цих речовин. У всіх видів синтезуються також лактони, і лише у $V$. lychnitis та $V$. nigrum виявлені кумарини (Karimova, 1974; Budancev, 1996).

У цих видів виявлено високий вміст водорозчинних цукрів (6,48-18,96 в \% від абсолютно сухої маси), слизу і пектинових речовин (від 3,87 до 39,98\%), кро- хмалю $(0,1-0,5 \%)$, особливо в пелюстках квітів, геміцелюлози (4,84-9,53\%) і клітковини (7,7-29,7\%). Причому найбільша їх кількість нагромаджується в коренях рослин (Karimova, 1974). Багаті представники цього роду аскорбіновою кислотою, зокрема в суцвітті $V$. lychnitis у фазі бутонізації міститься 74,88 мг/\%; у $V$. nigrum i $V$. phoeniceum в пелюстках $-120,0$ i 147,0 , тимчасом як в листках iіi нагромаджується в 4 i 2 рази менше, відповідно до виду. У $V$. thapsiforme навпаки, в пелюстках вміст вітаміну С становить 30,72 , тимчасом як в листках його нагромаджується вдвічі більше, а у $V$. thapsus велика кількість цієї сполуки нагромаджується і в суцвітті, і в листках (Karimova, 1974; Budancev, 1996).

Іранські вчені виявили великий вміст ефірних олій у надземній частині рослин у Verbascum songaricum. Ними було ідентифіковано вісімнадцять компонентів ефірних олій, 3 яких 88,5\% - аліфатичні вуглеводи. Найчастіше зустрічаються n-октан $(61,2 \%)$, п-декан $(15,6 \%), \quad$ п-додекан $\quad(4,6 \%), \quad 1$-етил-3метилциклопентан (4,2\%) і 6,10,14-триметил-2пентадеканон (3,2\%) (Soltaninejad and Akhgar, 2015).

Метою наших досліджень було більш детальне вивчення вмісту біологічно-активних речовин у підземних та надземних вегетативних і генеративних органах видів роду Verbascum, зібраних у Львівській області.

\section{Матеріал і методи досліджень}

Нами було проведено дослідження вмісту біологічно активних речовин у таких видів роду дивина (Verbascum L.) 3 родини ранникові (Scrophulariaceae L.): дивини скіпетровидної ( $V$. densiflorum syn $V$. thapsiforme Schrad.), д. залізняковидної ( $V$. phlomoides L.), д. борошнистої (V. lychnitis), д. чорної ( $V$. nigrum L.), д. тарганячої (V. blattaria L.), д. фіолетової ( $V$. phoeniceum L.). Більшість видів за життєвою формою є дворічниками, лише $V$. nigrum $i$ V. phoeniceum - стрижнекореневими багаторічниками. Для дослідження відбирали розеткові пагони першого року життя та корені, листки i пелюстки квітів з генеративних пагонів другого року життя у фазі цвітіння.

Дослідження вмісту біологічно активних речовин в органах різних видів рослин проводили за методикою Н.I. Гринкевич (Grinkevich, 1983) в лабораторії кафедри екології та біології університету. Як екстрагенти використовувалися такі розчинники: вода, 1\% розчин хлористоводневої кислоти та $70 \%$ етиловий спирт. Визначення алкалоїдів проводили у хлористоводневому екстракті за допомогою реактивів Драгендорфа, Бушарда, Майєра, Зонненштейна, розчину таніну та пікринової кислоти. У водних екстрактах 3 органів рослин досліджуваних видів виявляли сапоніни реакціями піноутворення та Фонтач-Кендела; дубильні речовини - реакцією з розчином залізоамонійного галуну, водорозчинних поліцукрів - реакцією 3 96\% етанолом та аскорбінової кислоти - реакцією 3 2,6-дихлорфеноліндодієноляту. У спиртовій витяжці виявляли флавоноїди - ціанідиновою пробою та реак- 
цією з солями важких металів і кумарини - реакцією 3 солями діазолінів та лактоновою пробою.

\section{Результати та їх обговорення}

Вважається, що вміст біологічно активних речовин $\epsilon$ подібним у систематично близьких видів (Hrodzynskoho, 1991). Проведемо порівняльний аналіз вмісту цих речовин у генетично близьких видів. Згідно існуючої системи рід Verbascum L. за будовою суцвіття розділяється на дві секції Fasciculata Murb. та Singuliflora Murb. До першої відносяться види, в пазухах приквітків яких міститься багато квіток, що утворюють так звані «пучки». До другої секції відносяться види, в пазухах приквітків яких розташовані поодинокі квітки (V. blattaria і $V$. phoeniceum). В свою чергу секція Fasciculata на основі будови андроцею поділяється на дві підсекції Heterandra Franch. ex
Murb. (пиляки двох передніх тичинок довгасті і збігають на нитки, трьох задніх - нирковидні ( $V$. thapsiforme, $V$. phlomoides) Рослини цих видів $є$ сильно опушені, а їх листки збігають на стебло, утворюючи крила. У видів підсекції Isandra Franch. ex Murb. (V. lychnitis, V. nigrum) пиляки усіх тичинок нирковидні. Окрім того, у $V$. nigrum і $V$. blattaria тичинки, а у $V$. phoеniceum - пелюстки квіток - фіолетово забарвлені. Тоді як у інших видів і тичинки, і пелюстки жовті.

Внаслідок проведених досліджень, було встановлено, що всі види роду Verbascum, нагромаджують у підземних і надземних органах такі біологічно активні речовини. Оскільки в попередніх дослідженнях нами не було виявлено серцевих глікозидів і антраглікозидів їх визначення ми не проводили (Berko and Hrytsyna, 2000; Zuzuk et al., 2008).

Вміст біологічно активних речовин в органах різних видів Verbascum L.

Таблицяя

\begin{tabular}{|c|c|c|c|c|c|c|c|c|c|}
\hline \multirow[b]{2}{*}{ № } & \multirow[b]{2}{*}{ Назва виду } & \multirow[b]{2}{*}{ Органи рослини } & \multicolumn{7}{|c|}{ Біологічно активні речовини } \\
\hline & & & 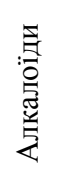 & 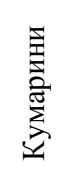 & 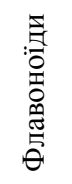 & 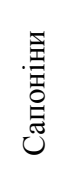 & 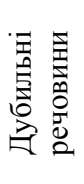 & 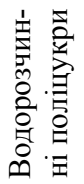 & 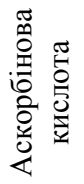 \\
\hline \multirow[t]{4}{*}{1.} & \multirow{4}{*}{$\begin{array}{l}\text { Дивина скіпетровидна } \\
\text { (Verbascum thapsiforme) }\end{array}$} & Розеткові листки & ++ & ++ & ++ & ++++ & ++ & ++ & +++ \\
\hline & & Корені & - & +++ & ++ & +++ & ++ & +++ & ++ \\
\hline & & Стеблові листки & - & + & ++ & +++ & + & +++ & + \\
\hline & & Пелюстки & - & +++ & ++ & +++ & ++ & ++ & ++ \\
\hline \multirow[t]{4}{*}{2.} & \multirow{4}{*}{$\begin{array}{c}\text { Динина залізняковидна } \\
(V . p h l o m o i d e s)\end{array}$} & Розеткові листки & ++ & +++ & ++ & +++ & ++ & +++ & +++ \\
\hline & & Корені & - & +++ & ++ & + & +++ & +++ & + \\
\hline & & Стеблові листки & + & + & ++ & ++ & +++ & ++ & + \\
\hline & & Пелюстки & - & ++ & ++ & ++ & ++ & ++ & ++ \\
\hline \multirow[t]{3}{*}{3.} & \multirow{3}{*}{$\begin{array}{c}\text { Дивина волотиста } \\
(\text { V. lychnitis })\end{array}$} & Розеткові листки & ++ & +++ & ++ & + & +++ & ++ & + \\
\hline & & Стеблові листки & + & +++ & ++ & +++ & +++ & ++ & + \\
\hline & & Пелюстки & - & ++ & ++ & ++ & +++ & ++ & +++ \\
\hline \multirow[t]{4}{*}{4.} & \multirow{4}{*}{$\begin{array}{c}\text { Дивина чорна } \\
\text { (V. nigrum })\end{array}$} & Розеткові листки & + & +++ & ++ & +++ & +++ & ++ & + \\
\hline & & Корені & - & +++ & +++ & +++ & + & +++ & + \\
\hline & & Стеблові листки & - & +++ & ++ & +++ & +++ & ++ & + \\
\hline & & Пелюстки & + & + & +++ & +++ & +++ & ++ & +++ \\
\hline \multirow[t]{4}{*}{5.} & \multirow{4}{*}{$\begin{array}{c}\text { Дивина тарганяча } \\
\text { (V. blattaria) }\end{array}$} & Розеткові листки & + & +++ & ++ & +++ & +++ & +++ & +++ \\
\hline & & Корені & - & ++ & ++ & +++ & + & +++ & ++ \\
\hline & & Стеблові листки & - & + & ++ & +++ & + & ++ & + \\
\hline & & Пелюстки & + & + & +++ & + & +++ & ++ & + \\
\hline \multirow[t]{3}{*}{6.} & \multirow{3}{*}{$\begin{array}{c}\text { Дивина фіолетова } \\
\text { (V.phoeniceum) }\end{array}$} & Розеткові листки & + & +++ & +++ & +++ & ++ & ++ & ++ \\
\hline & & Корені & - & +++ & +++ & +++ & + & + & ++ \\
\hline & & Пелюстки & + & + & +++ & +++ & ++ & ++ & +++ \\
\hline
\end{tabular}

Умовні позначення: +++ - вміст БАР високий; ++ - достатній; + - низький (сліди); - сполука відсутня.

Алкалоїди в дуже малій кількості нагромаджуються в коренях і пелюстках всіх видів. Проте все ж видно деяку закономірність, в розеткових листках сильноопушених видів підсекції Heterandra і V. lychnitis 3 підсекції Isandra їх є значно більше, ніж в інших органах. У менш опушених, фіолетово забарвлених видів - V. nigrum, V. blattaria і $V$. phoeniceum виявлено лише сліди алкалоїдів.

У всіх органах $V$. thapsiforme у великій кількості синтезуються сапоніни, завдяки чому вони проявляють відхаркувальні властивості. Дещо менший вміст цих речовин $є$ у близького виду $V$. phlomoides 3 підсе- кції Heterandra. Два інші види з підсекції Isandra, які $\epsilon$ неофіцинальними, нагромаджують також сапоніни. Так, V. lychnitis у коренях і розеткових листках у великій кількості, дещо менше у стеблових листках і пелюстках, $V$. nigrum та $V$. blattaria і $V$. phoeniceum (секція Singuliflora) - у всіх органах в дуже високій кількості.

У досліджуваних видів виявлені дубильні речовини, особливо в великій кількості у V. Lychnitis, $V$. nigrum i $V$. phlomoides. Ці сполуки мають в'яжучу дію та проявляють антимікробні властивості, що було доведено в експерименті (Nasyrov et al., 1974; Zuzuk et 
al., 2008). Всі види досліджуваного роду мають протизапальну дію.

Флавоноїди нагромаджуються у всіх органах досліджених видів, а у V.nigrum, V. blattaria i $V$. phoеniceum, що мають фіолетово забарвлені елементи квітки - у дуже великій кількості в пелюстках квіток. Ці фенольні сполуки мають дію на серцевосудинну систему, заспокійливу - на нервову систему та проявляють бактерицидні властивості. Подібну дію мають кумарини, які в значно більшій кількості нагромаджуються в розеткових листках пагонів першого року життя та коренях генеративних пагонів, ніж в стеблових листках та пелюстках квіток (таблиця). Дещо менший їх вміст спостерігається у надземній частині $V$. blattaria і пелюстках $V$. phoeniceum. Екстракти, виготовлені з надземної частини $V$. lychnitis, $V$. nigrum, $V$. phoeniceum в експерименті стимулювали серцево-судинну діяльність і підвищували кров'яний тиск, вони заспокійливо впливали на центральну нервову систему (Kuz'mina et al., 1985; Hrodzynskoho, 1991; Budancev, 1996). Насіння цих рослин, особливо $V$. thapsus має легко наркотичні властивості. Види досліджуваного роду мають седативну діють та одурманююче впливають на риб. Ця дія зумовлена наявністю в їх органах наркотичних речовин - кумаринів і флавоноїдів (Nasyrov et al., 1974). Крім цього, $V$. thapsus та $V$. blattaria проявляють інсектицидні властивості відносно до молі, личинок москітів та деяких інших комах (Budancev, 1996).

У великій кількості синтезуються у всіх видів водорозчинні поліцукри, особливо багато їх є у коренях. При кількісному їх визначенні виявилося, що у листках $V$. thapsiforme їх вміст становить 29,73\% сухої маси, а пелюстках квіток - лише 4,76\% від сухої маси. Значно менший вміст полісахаридів є у V. lychnitis 2,64\% у пелюстках і 8,24\% у листках. В найбільшій кількості аскорбінова кислота міститься у в пелюстках квіток $V$. lychnitis i $V$. nigrum, тимчасом як в інших органах - iï $є$ мала кількість. У $V$. blattaria, $V$. thapsiforme i $V$. phlomoides у розеткових листках вона $\epsilon$ у великій кількості, а в пелюстках - у малій. Всі види роду Verbascum є пилко- та медоносами. Найбільшим нектаропродуцентом вважається $V$. nigrum, у якого на одну квітку виділяється 0,36-1,03 мг нектаpy, на рослину - 0,16-1,25 гр. В складі цукрів нектару переважає фруктоза - 68\%, що на 25\% більше, ніж у гречки та на 30\% більше, ніж у липи (Kucherov and Syroeva, 1980).

\section{Висновки}

Всі види роду Verbascum нагромаджують у підземних і надземних органах такі біологічно активні речовини: алкалоїди, кумарини, флавоноїди, сапоніни, дубильні речовини, водорозчинні поліцукри та аскорбінову кислоту. Причому неофіцинальні види $V$. lychnitis, $V$. nigrum, $V$. blattaria i $V$. phoeniceum нагромаджують БАР в більшій кількості, ніж ті, що використовуються в офіційній медицині ( $V$. phlomoides i $V$. thapsiforme).

Встановлена деяка прив'язаність вмісту БАР залежно від систематичного положення виду. Алкалоїдів в розеткових листках сильноопушених видів 3 жовтими квітами $V$. phlomoides, $V$. thapsiforme i $V$. lychnitis $\epsilon$ значно більше, ніж в інших органах. У менш опушених, фіолетовозабарвлених видів $-V$. nigrum, $V$. blattaria і $V$. phoeniceum виявлено лише їх сліди. Всі досліджувані види нагромаджують сапоніни в великій кількості незалежно від систематичного положення. Флавоноїди нагромаджуються у всіх органах досліджених видів, а у $V$. nigrum, $V$. blattaria i $V$. phoeniceum, що мають фіолетово забарвлені елементи квітки - у дуже великій кількості в пелюстках квіток. Кумарини в значно більшій кількості нагромаджуються в розеткових листках пагонів першого року життя та коренях генеративних пагонів, ніж в стеблових листках та пелюстках квіток, особливо фіолетово забарвлених видів. У досліджуваних видів виявлені дубильні речовини, особливо у $V$. lychnitis $V$. nigrum i V. phlomoides.

У великій кількості синтезуються у всіх видів водорозчинні поліцукри, особливо багато їх $є$ у коренях. Аскорбінова кислота в найбільшій кількості міститься у пелюстках квіток $V$. lychnitis i $V$. nigrum, тимчасом як в інших органах - iі $\epsilon$ дуже мала кількість. У $V$. blattaria, $V$. thapsiforme i $V$. phlomoides навпаки, у розеткових листках виявлена у великій кількості, а в пелюстках квіток - у малій.

\section{Бібліографічні посилання}

Berko, Y.M., Hrytsyna, M.R. (2000). Do biokhimichnoi kharakterystyky rodu Dyvyna (Verbascum L.) flory Lvivshchyny. Nauk. visnyk LDAVM im. S.Z. Hzhytskoho. 2(2), 3-6 (in Ukrainian).

Zuzuk, B.I., Kutsyk, R.V., Hrytsyna, M.R., Berko, Y.M. (2008). Dyvyna skipetrovydna. Provizor. 7, 54-59 (in Ukrainian).

Dohot, A.V., Lytvynenko, V.I., Chornykh, N.O., Zoz, I.H. (1972). Irydoidy v rodyni rannykovykh. Farmatsevtychnyi zhurnal. 27(1), 66 (in Ukrainian).

Karimova, S.G. (1974). Biologicheskie i biohimicheskie osobennosti nekotoryh predstavitelej semejstva norichnikovyh (Scrophulariaceae). Dikorastushhie i introduciruemye poleznye rastenija v Bashkirii. Ufa. 4, 89-104 (in Russian).

Kuz'mina, L.V., Kuznecova, G.A., Ulicheva, G.M. (1985). Ihtiotoksicheskaja aktivnost' nekotoryh vidov roda Verbascum L. otechestvennoj flory. V kn. Podgotovka ozer pitomnikov himicheskim metodom. L. 234, 29-36 (in Russian).

Kotov, M.I. (1960). Rid Dyvyna - Verbascum L. Flora URSR. K. Vyd. AN URSR. 9, 407-431 (in Ukrainian).

Kucherov, E.V., Syroeva, S.M. (1980). Medonosnye rastenija Bashkirii. M. (in Russian).

Hrodzynskoho, A.M. (1991). Likarski roslyny Entsyklopedychnyi dovidnyk. Kyiv. URE (in Ukrainian).

Nasyrov, H.M., Karimova, S.G. (1974). Farmakologija flavonoidov korovjaka metel'chatogo. Dikorastushhie $\mathrm{i}$ introduciruemye poleznye rastenija $\mathrm{v}$ Bashkirii. Ufa. 4, 114-118 (in Russian). 
Nasyrov, H.M., Voroshilova, N.I., Gluharev, Ju.A. (1974). Antibakterial'nye svojstva nekotoryh rastenij semejstva norichnikovyh. Dikorastushhie i introduciruemye poleznye rastenija $\mathrm{v}$ Bashkirii. Ufa. 4, 104-108 (in Russian).

Budancev, A.L. (1996). Rastitel'nye resursy Rossii i sopredel'nyh gosudarstv. [Otv. red.]. S. P. «Mir i sem'ja - 95». 168-169 (in Russian).

Serdjuk, L.I., Dzhumyrko, S.F., Kompancev, V.A. (1976). Irydoidy i flavonoidy Verbascum lychnitis. Himija prirodnyh soedinenij, 4, 545-546 (in Russian).

Grinkevich, N.I. (1983). Himicheskij analiz lekarstvennyh rastenij. M. Vysshaja shkola (in Russian).

Danchul, V.Ju., Hanin, V.A., Shagova, L.I., Shavarda, A.L. (2007). Flavonoidy nekotoryh vidov roda Verbascum (Scrophulariaceae) Rastitel'nye resursy. 43(3), 92-102 (in Russian).

Shreter, A.Sh., Eremin, A.V., Glazyrina, Z.Ja. (1969). Predvaritel'nye itogi poiskov saponinosoderzhashhih rastenij v flore SSSR. Materialy 6-j Ural'skoj konferencii fiziologov, farmakologov $\mathrm{i}$ biohimikov ( $\mathrm{g}$. Tjumen'). Sverdlovsk. 405-407 (in Russian).

Gazar, H.A., Tasdemir, D., Ireland, C.M., Calis, I. (2003). Iridoids and triterpene saponins from Verbascum wiedemannianum (Scrophulariaceae). Biochem. System. and Ecology. 31(4), 433-436.

Kalpoutzakis, E., Aligiannis, N., Mitakou, S., Skaltsounis, A.-L. (1999). Verbaspinoside, a new iridoid glycoside from Verbascum spinosum. Elefterios Kalpoutzakis, J. Nat. Prod. 62(2), 342-344.
Klimek, B., Krolikovska, M. (1984). Zwiazki flawonoidowe w kwiatach dziewanny wielkokwiatowey - Verbascum thapsiforme Schrad. i dziewanny kutnerowatey - Verbascum phlomoides L. (Scrophulariaceae) Acta pol. Pharm. 41(2), 259-264.

Klimek, B., Catherine, L., Georces, M. (1992). Saponins from Verbascum nigrum. Phytochemistry. 31(12), 4368-4370.

Seifert, K., Preiss, A., Siegfried, J., Schmidt, J., Nguyen, T. (1991). Triterpene saponins from Verbascum songaricum. Phytochemistry. 30(10), 3395-3400.

Soltaninejad, M., Akhgar, M.R. (2015). Chemical composition of the essential oil of Verbascum songaricum from Iran. J. Bio. \& Env. Sci. 26, 345-349.

Swiatec, L., Kurowska, A., Rotkiewich, D. (1984). Analisa kwasow tluszcowych i fenolowych, wystepujacych we flos verbasci. Herba pol. 30, 3(4), 173-181.

Swiatec, L. Luczak, S., Irabis, B. (1984). Wystepowanie irydoidow w roznuch organach Verbascum thapsiforme Schrad. i Verbascum phlomoides L. Farm. pol. 40(7), 415-418.

Magiatis, P., Melliou, E., Tsitsa, E., Charvala, C., Mitaku, S. (2000). Two new acylated iridoid glycosides from Verbascum undulatum https://doi.org/10.1515/znc2000-7-829.

Warashina, T., Miyase, T., Ueno A. (1991). Iridoid glycosides from Verbascum thapsus L. Chemical and Pharmaceutical Bu. 39(12), 3261-3264.

Стаття надійшла до редакції 14.03.2017 